\title{
QUEST FOR SCOTTISH INDEPENDENCE IN JAMES ROBERTSON'S SHORT FICTION ON THE EVE OF THE REFERENDUM
}

\author{
UDC 821.111(411).09 Robertson J.
}

\author{
Milena Kaličanin \\ University of Niš, Faculty of Philosophy, Niš, Serbia
}

\begin{abstract}
The paper focuses on a detailed analysis of Robertson's personal queries related to the issue of Scottish independence in two short stories, Republic of the Mind (first published in 1993) and MacTaggart's Shed (2012). Since there is a conspicuous time span in-between the publication of these stories, it is our purpose to track, explore and describe how Robertson's treatment of the same subject has changed over the years, particularly having in mind the references to the Devolution Referendum (1997) and Independence Referendum (2014) in these stories. Bearing in mind the idea of an artist as an active communal participant (Rich, 1993), Robertson ostensibly favours the political cause of Scottish independence; however, his short stories depict his personal doubts about its realization in future practice, a stance that proved to be completely justified after the unsuccessful Independence Referendum (2014). The theoretical framework of the paper relies on the critical insights of Scottish scholars, Campbell, Taylor, Thompson and Massie, as well as numerous contemporary journalist accounts of Scottish political analysts.
\end{abstract}

Key words: independence, devolution, Devolution Referendum 1997, Scottish Independence Referendum 2014.

\section{INTRODUCTION}

At a literary debate in Edinburgh in the mid-1980s, James Robertson heard one of the speakers - "a well-known Scottish novelist" - express the observation that "there are no politics in Scotland", which, as was explained, illustrated the main point for setting many of his novels abroad - Italy, France or England. This author disappointedly stated that "nothing of great importance ever happens here" (Campbell 2010: 1). James Campbell insightfully reveals in his 2010 article in The Guardian dedicated to innovative Scottish literary voices of the $21^{\text {st }}$ century, that the controversial writer in question turned out to be

Submitted May $1^{\text {st }} 2017$, accepted for publication July $21^{\text {st }}, 2017$

Corresponding author: Milena Kaličanin

Faculty of Philosophy, Ćirila i Metodija 2, 18000 Niš, Serbia

E-mail: milena.kalicanin@filfak.ni.ac.rs 
Allan Massie, whose subjective depiction of Scotland as a backwater, where nothing of great political importance happened from the Union of the Parliaments in 1707, did not correspond to Robertson's enthusiastic political attitudes at the time. In the interview with Campbell, Robertson recalls his reaction to the previous shocking statement: "There was a general drawing-in of breath. I thought: how dare you!" (Campbell 2010: 1)

Although Robertson's "gasp of disbelief" was the loudest at the aforementioned literary debate, nowadays he peacefully concedes that "in a way, what Massie was saying was true" (Campbell 2010: 1). According to Campbell, Robertson's role as a conscientious, provocative Scottish writer has thus been to detect, trace and creatively express the modest, but rather appreciable change in the Scottish cultural climate from the mid-1980s onwards:

The country had survived and prospered as a client state of England and the British Empire, but a sense of dissatisfaction had grown throughout the 20th century. Scotland's capital city was "not a centre but a blank", as the poet and critic Edwin Muir notoriously put it in the 1930s. Robertson is the latest in a line of modern writers who have queued up to stuff the blank with words. (Campbell 2010: 1)

Listed along with Irvine Welsh and James Kelman, Robertson has tackled varied subject matters relevant for the shaping of modern Scottish identity, devolution and independence, among others. Challenging and demanding as they seem, these subject matters have occupied a significant part of Robertson's work, in which he offers "a series of inventive, meticulously researched attempts to document Scotland's past and present” (Taylor 2012: 1), simultaneously combined with creative insights into the nation's collective future.

Bearing in mind the idea of an artist as an active communal participant (Rich 1993), Robertson ostensibly favours the political cause of Scottish independence (Tychy 2013); however, his short stories depict his personal doubts about its realization in future practice, a stance that proved to be completely justified after the unsuccessful Independence Referendum (2014). The paper focuses on a detailed analysis of Robertson's personal queries related to the issue of Scottish independence in two short stories, Republic of the Mind (first published in 1993) and MacTaggart's Shed (2012). Since there is a conspicuous time span in-between the publication of these stories, it is our purpose to track, explore and describe how Robertson's treatment of the same subject has changed over the years, particularly having in mind the (in)direct references to the Devolution Referendum (1997) and Independence Referendum (2014) in these stories. ${ }^{1}$

\section{REPUBLIC OF THE MIND}

The title story of Robertson's Republics of the Mind commences with a violent reaction of a Scottish woman who throws an empty wine bottle at her television screen utterly disappointed by the victory of the Conservative party on an unspecified election night. This savage act, caused by watching an interview with a smug, self-gloating government (conservative) minister, further results in the prompt explosion of the TV set.

\footnotetext{
${ }^{1}$ It is important to note that the first eleven of the twenty two stories in Republics of the Mind (2012), including the title story from this collection, were published originally in The Ragged Man's Complaint (1993), four years prior to Scotland's devolution referendum, and they reappear in the new volume of short stories two years ahead of the vote on independence (see Tychy 2013). Our intention is to probe into the author's reasons for the republication of this story on the eve of the Independence Referendum.
} 
For Robertson, this clear illustration of the rough intensity of feelings should not be related only to this particular Scottish woman, but to the Scottish nation in general. The feelings of utter disappointment and frustration shared by the majority of Scots represented a logical outcome of the governmental elections during the 1980s, in which the infamous "Iron lady", Margaret Thatcher, had even thrice obtained her political victory (first in 1979, afterwards in 1983 and 1987).

Thatcher's inflexible politics has frequently been associated with ambiguously notorious concepts such as anti-communism, anti-trade unionism, euro-scepticism, home ownership, monarchism, capitalism and conservatism. Her ethical outlook and personal preferences, among which she constantly emphasized moral absolutism, nationalism and core interest in the individual, combined with a Machiavellian uncompromising approach to achieving political goals, earned her an infamous nickname, given by the most ferocious British foreign adversaries at the time, the Soviets. Apart from the recurring scandals in foreign policy, whereby she got repeatedly (and justifiably!) accused of racist and xenophobic tendencies, Thatcher brought upon herself the overall dissatisfaction of the people of the UK, particularly its non-English constituent members. With her insistence on the economic, political and moral responsibility of the individual for his/her social status, Thatcher was unashamedly obliterating the indispensible impact of the Government in this area, which, consequently, led to a significant increase in the gap between the rich, well-to-do south-east of the country and the poor, undeveloped north-west. Although causing a great rate of unemployment and social unrest in the UK, she frankly displayed her political goals and selfish lack of care for individual demands in an interview with Douglas Keay in 1987:

I think we have gone through a period when too many children and people have been given to understand "I have a problem, it is the Government's job to cope with it!" or "I have a problem, I will go and get a grant to cope with it!" "I am homeless, the Government must house me!" and so they are casting their problems on society and who is society? There is no such thing! There are individual men and women and there are families and no government can do anything except through people and people look to themselves first. It is our duty to look after ourselves and then also to help look after our neighbour and life is a reciprocal business and people have got the entitlements too much in mind without the obligations. (Thatcher 1987)

The insistence on the claim that "there is no such thing as society" gained a great approval on the part of the leading conservative British circles at the time; however, the young, urban, enlightened people with modern tendencies regarded this statement as criminal and unlawful, to say the least. ${ }^{2}$ Such people are depicted in Robertson's story.

Kate and Robert from Robertson's story engage themselves in completely opposed means of protest against this politically imposed egotism. Whereas Kate resorts to a meaningless and futile act of violence, Robert does not make great fuss about his revolt; his means of protest are more inconspicuous and unobtrusive. Robert retreats into his personal utopian fabrication, "the Scottish republic of the mind" (Robertson 2012: 133), an imagined state with the aim of presenting "an antidote to post-election hangover" (Robertson 2012: 134), which he defines in the following fashion:

\footnotetext{
${ }^{2}$ The only positive trait of Thatcher's political engagement can be seen in the political analysis of Alex Salmond, the fourth Scottish Prime Minister (2007-2014), given in The Herald, shortly after Thatcher's death in 2013, that "her policies had the unintended consequence" (Dinwoodie 2013) of encouraging Scottish devolution.
} 
It was more than some utopian fantasy about the country. It filled the gap between actuality and possibilities of all kinds...It was a state of being in which all the people understood themselves, and what they were doing and why they were where they were. The more often you got there, the longer you stayed. And this was the secret of it - it didn't depend on the politicians at all. It didn't need constitution and laws, but simple self-determination...It was like going up to the mountain and coming down whole. (Robertson 2012: 134-135)

Both Kate's and Robert's means of protest against politically prescribed selfpreservation methods reveal the sorrowful and helpless state that the urban young people of Scotland found themselves three decades ago. In this story, Robertson masterfully describes the characters that are utterly powerless over their own lives, which he potently parallels with the powerless political state of the Scottish nation: the young people "cannot expect to be saved from their personal dissatisfactions by a nation that is equally unfree" (Tychy 2013: 2).

According to Taylor, this blend of political and personal is typical of Robertson's work (Taylor 2012:1). In the words of Kate from Republic of the Mind, "they were less than whole because of how their country was" since "all we are doing is waiting" (Robertson 2012: 150) Kate frankly reveals that her nation suffers from constant communal lethargy and utter political disorganization, so that a logical outcome of this permanent state is the conspicuous lack of control over its own political destiny. It is not the much loathed English that should be blamed for this state, not even the infamous Iron Lady and her conservative political pawns - Kate is primarily disgusted with the fact that Scotland is represented by utterly corrupt and detached politicians; in her opinion, paradoxically, Scotland should be even stripped of "the dignity of being subjugated" (Tychy 2013:2), since it cannot produce (let alone agree on!) an official, meaningful way of resisting English political and economic domination.

The main question raised in the story is whether these two ways of protest are valid and substantial. Robertson depicts Kate's throwing of the wine bottle at the television screen during an election night as the only revolutionary political act thus literally switching off politics with the final image of the minister's face exploding. On the other hand, Robert's utopian vision of his personal republic of the mind consists of precious, intimate moments, whereby the danger lies evidently in "mystifying politics and of politicising intimacy" (Tychy 2013:2):

Robert's republic may seem like ointment for an existential itch, rather than freedom for the genuinely oppressed. An important concession has been made when amending Robert's "republic of the mind" to Robertson's Republics of the Mind. The former potentially confirms Thatcher's supposed maxim, "There is no such thing as society." (Tychy 2013:2)

In accordance with Thatcher's maxim, Robert's means of protest against political hypocrisy is totally egoistic and remote from important collective and communal demands. The sole meaningful way to achieve the utopia Robert hopes for is indicatively hinted at: when Scotland finally secedes from the UK, he will let his kite "fly off like a real thing, like a live thing" (Robertson 2012: 148). At the end of the story, Robertson depicts his main character alone in his utopia, conversing with a hallucinogenic seal, exclaiming "I love you, I love you, I love you" (Robertson 2012: 151), which may be interpreted as the author's ultimate warning that "political disengagement similarly engenders loneliness and relativism" (Tychy 2013:4). 


\section{ROBERTSON'S ARTISTIC QUEST}

Republic of the Mind was originally written four years prior to the Devolution Referendum (1997). Robertson obviously felt the need to creatively depict the dominant flair of political stagnation and disinterest, as well as the conspicuous lack of meaningful strategies for obtaining the home rule on the part of the majority of the Scottish population during the 1990s. Therefore, this particular story should not be interpreted as the author's willing approval of the described means of political protest, but rather as his artistic call for the final awakening of the Scottish nation, whose main preoccupation should definitely be the unfaltering vote for the home rule at the Devolution Referendum scheduled for 1997. Robertson was painfully aware of the unsuccessful attempts at establishing the home rule before the 1997 Referendum: first, the failed Devolution Referendum in 1979, when the majority of the Scottish population did not even recognize the political importance of the event and, consequently, did not turn up and vote; "before that", in the words of the BBC commentator, Brian Taylor, "there had been a century of varying efforts to devolve power to Scotland. Before that, there had been advocacy of Scottish self-determination in various forms dating back to the Union of the Parliaments of Scotland and England in 1707" (Taylor 1997:1). Evidently, Robertson did not take a standing joke in Scotland at the time that - "devolution resembles evolution, but takes longer" (Taylor 1997:1) - quite well, to say the least.

The inspiring results of the 1997 Devolution Referendum implied the foundation of an elected, devolved Scottish Parliament, whose principal role would be to legislate for matters affecting Scotland: areas such as education, health, the criminal law, the environment and industrial support. However, matters such as defence, foreign policy and the broad economy were still to be run by Westminster. As the first writer-in-residence in the Scottish Parliament, Robertson set out on an artistic quest to share his optimistic vision of future Scottish independence with the rest of the world (devolution, of course, being just a valid beginning of this highly desired political goal). When writing about the new premises of the Scottish Parliament, Robertson proudly stated: "It is impressive rather than magnificent, stylish rather than grand, humorous rather than staid, welcoming rather than imposing, celebratory rather than monumental. It invites comment and challenges preconceptions...It honours history but projects itself into the future. It seems right for 21st century Scotland" (Robertson 2005: 11).

The immense respect for tradition and history represents a constant in Robertson's political outlook and creative work that goes hand in hand with a potent wave of optimism he experienced regarding the Scottish future after the 1997 Devolution Referendum. It is precisely this optimistic flair that is understandably missing from Kate's and Robert's treatment of current politics, whereby the feeling of utter helplessness dominates their lives. Many literary critics argued that in Republic of the Mind, the true capacity of Robertson, the artist, could not be properly expressed, since the power of his idealistic political convictions has always been reflected in his work and it is noticeably lacking in Republic of the Mind. For instance, Taylor claims that "Robertson's treatment of political issues in Republics of the Mind lacks the punch of his wonderful poem 'A Manifesto for MSPs' in Voyage of Intent" (Taylor 2012: 2). Here is the poem:

Dinna be glaikit, dinna be ower smert,

dinna craw croose, dinna be unco blate,

dinna breenge in, dinna be ayewis late, 
dinna steek yer lugs, dinna steek yer hert.

Dinna be sleekit, dinna be a sook,

dinna creesh nae loof for future favour,

dinna swick nor swither, hash nor haiver,

dinna be soor o face, and dinna jouk.

Open yer airms and minds tae folk in need,

hain frae fylin and skaith the land and sea,

tak tent o justice and the commonweal,

ding doon hypocrisy, wanthrift and greed,

heeze up the banner o humanity,

seek oot the truth and tae the truth be leal. (Robertson 2005: 21) ${ }^{3}$

The poem, as Taylor claims, "delights in its hoard of Scots words, serving as both a political manifesto and a means of connection to Scotland's rich literary heritage. In a moment of characteristic sincerity, Robertson said that he hoped that each MSP (Member of the Scottish Parliament) would pin the poem on their wall. It is this unabashed, heartfelt idealism that makes Robertson a favourite among his readers, as well as endearing him to Scotland's left" (Taylor 2012:2). For Robertson, the Scottish Parliament did not only represent an impressive building, but "a voyage of intent, a journey to whatever we might be" (Robertson 2005: 24), as he claimed in another poem from the same collection, symbolically entitled "The Voyage". The unabashed, heartfelt idealism that Taylor talks about is potently captured in the poem's closing lines:

This is our new departure, this is what

we opted for, solid and permanent,

yet tenuous with possibility. (Robertson 2005: 24)

\section{MACTAGGART's SHED}

Although it seems that Robertson was finally bursting with enthusiasm regarding the Scottish question at the beginning of the new millennium, it is rather interesting to probe into his reasons for the reprint of Republic of the Mind two decades after its first publication, quite literally on the eve of the Scottish Independence Referendum that was finally scheduled for September 2014. Bearing in mind the prevailing feelings of political discontent, as well as a simultaneous absence of political activism and engagement on the part of the majority of Scottish voters, Robertson found it necessary not only to reprint this particular story, but also to portray a horrifying dystopian vision of the future of Scotland in MacTaggart's Shed, the most disquieting story in the volume Republics of the Mind (2012), as Jaqueline Thompson observes (Thompson 2012:2).

MacTaggart's Shed is set in a future dystopian version of Scotland where ethnic cleansing occurs. The story commences with the depiction of the main character, Christie, who wakes up in the armchair where he has spent the night. When he looks out of his window, an unaccepted event occurs - Christie perceives ghosts crossing the field where MacTaggart's shed used to be: "The sight of the ghosts should have filled him with horror, but he felt only a dull stirring of the old fear that had been with him for months"

\footnotetext{
${ }^{3}$ The poem is purposefully written solely in Scots, although the author uses a combination of both English and Scots in his writing.
} 
(Robertson 2012: 240). According to Massie, a writer mentioned at the beginning of this paper as one of Robertson's political opponents, this is a splendid opening of the story: "you want to know about the ghosts - are they indeed ghosts? - and about the reason for his old fear" (Massie 2012:2).

Leaving the significant question of fear unexplained, Robertson portrays Christie's brother-in-law, Malky, arriving with provisions, which leads to a series of other questions purposefully left unresolved. Why is this necessary? Why will Christie no longer leave his cottage? Why is Christie's sister, Malky's wife, afraid, as Christie himself is? Massie comments on the list of unresolved questions and states that Robertson is "disturbingly good" in his intention of making his readers probe into the depth of this unspecified, but rather intriguing issue:

We want to know why, and why Malky pretends that there is no reason for fear. We suspect that something terrible has happened. The colour of the story is dark-grey, the sense of horror pervasive and compelling. When Robertson writes in this vein, he is disturbingly good (Massie 2012:2)

Being inspired with the civil war in Yugoslavia during the 1990s, Robertson felt the need to describe a potential future threat of a civil war on the territory of Scotland/ the UK, if the Scottish nation did not formulate a common political stance regarding the independence issue. Written two years prior to the Independence Referendum, it is very likely that this story represents Robertson's warning about the possible consequences of its failure. It is also interesting to notice that after a great wave of enthusiasm that Robertson experienced as the first writer-in-residence in the Scottish Parliament at the beginning of the new millennium, he got extremely doubtful and suspicious regarding the Scottish question only a couple of years afterwards. Robertson insightfully perceived similar patterns and parallels with the independence cravings happening elsewhere in Europe, particularly in the former Yugoslavian republics and got terrified with the possible abominable scenario that could be enacted in his native land.

Thus in this story Robertson describes a future dystopia in Scotland. During an unspecified and unexplained civil conflict, the population of a small Scottish village is notoriously divided into warring parties. At first sight, Christie seems to be uninterested in these events, leading a detached life at the end of the village. However, at the insistence of his brother-in-law, Malky, he becomes a part of the procession in charge of the execution of some of his villagers. Allegedly accused of setting fire to MacTaggart's property and murdering young Jock MacTaggart, the group of six old man (including popular Sammy with his dog), four women and a couple of children are rounded up and processed to MacTaggart's shed by the unknown men wearing dark glasses and black leather jackets, including Christie and Malky. Christie is painfully aware of the fact that if he was not with the oppressors he would definitely become the oppressed one. At one point, he even hopes for the peaceful resolution of the issue, since the people in question, his friends and neighbours, could not have possibly done such a vicious act. Christie naively thinks that "it was as if somebody, with some brave, simple gesture, could change whatever was going to happen. I can dae something here, I can really dae something." (Robertson 2012: 254)

However, the main character of the story finally decides not to meddle into these strange affairs, although he has a rather clear premonition of the atrocity about to occur. He does not interfere even when the whole group of his former acquaintances was gathered in MacTaggart's shed, he remains silent to women's and children's cries for help: "Auld Sammy looked at Christie and he started to shout, he was shouting: 'Help us! Help 
us! Why are ye just standin there?' The man with the earring was watching intently. He didn't seem to see Sammy anymore: he was staring at Christie to see what he would do. To see if he would fuck up" (Robertson 2012: 255). The only substantial thing he makes himself promise is to take care of old Sammy's dog after Sammy is violently driven into the shed with the others. Soon, a clatter of gunfire is heard and Malky comes out of the shed entirely spotted with blood. After being yelled at about the impossibility of keeping Sammy's dog, Christie mercilessly shoots it.

Whether the events of people being herded into a shed to be executed are real or imagined is uncertain, so Robertson purposefully leaves his story open-ended. The man who witnesses these events, Christie, is ordered to forget them as if they had never happened. MacTaggart pulls down the shed and after a while he plants Brussels sprouts all over the field, as if the absence of the shed would signify the lack of circumstantial evidence regarding the unfortunate case. Christie is repeatedly being told by Malky that the whole tragic event was jus a product of his imagination: "Ye've been watchin too much shite on the telly. Aw these news programmes ye watch, the documentaries and aw that. That aw happens somewhere else. Other countries. No here. Ye're away wi the fairies" (Robertson 2012:257).

Christie is definitely certain that his experience was not imagined. However, it seems that although his heart is in the right place and can tell the difference between the right and wrong, his major handicap is that he is not courageous enough to stick to his principles, defend his attitudes, do something about the horrors he experienced and, ultimately, remain human:

He had to get in touch with the international boys, tell them about what had happened in the shed. He was a witness. All right, he had shot the dog, but only the dog, but he'd had no choice, they'd have killed him if he hadn't...He remembered the houses burning on the hillside. Terrible, terrible things had happened. He felt numb with the thought of all that hurt...he wondered if he would see the ghosts again, and how many there would be. He reached for the first bottle of whiskey, and started to plan what he would do in the morning. (Robertson 2012: 258)

Robertson's pessimistic prediction of Scotland's future based on an unfortunate foundation of a dystopian society characterized by totalitarian government and absolute dehumanization should be regarded as a warning about the potential social horrors in case the Independence referendum fails. Although an optimist and idealist to the core regarding the matter of Scottish Independence, it seems that Robertson intuitively felt the pulse of the Scottish nation and gloomily anticipated that the moment was still not right for making such radical political changes. In spite of the fact that the turnout of $84.6 \%$ was the highest recorded for an election or referendum in the UK, the party protesting against independence at the 2014 Scottish Independence Referendum was triumphant namely, $55.3 \%$ of the Scots voted against independence and $44.7 \%$ voted in favour.

Domestic reactions that followed utterly revealed the satisfying self-gloat of the winning party: in a politically correct fashion, Queen Elizabeth II claimed that it was "a result that all of us throughout the United Kingdom will respect" (The Queen's Message, 19 September 2014), but, as was afterwards reported, David Cameron, who himself was delighted with the results, commented that the Queen "had purred down the line" (Watt 2014: 1) when hearing the final result of the referendum. Whereas the British Prime Minister was feeling celebratory after the referendum, Alex Salmond, the Scottish Prime Minister at the time, confirmed that he would resign from his post, claiming that "for me 
as leader my time is nearly over but for Scotland the campaign continues and the dream shall never die". (Salmond on BBC News, 19 September 2014)

Immediately after the unsuccessful referendum in Scotland, allegations of voting irregularities were followed by frequent acts of violence on the streets of Glasgow and a significant increase in political activism, particularly regarding the new members of the Scottish National Party, one of the most passionate and radical supporters of the claim for Scottish independence. Although the extensive new powers were granted to the Scottish Parliament as a conciliatory aftermath of the Independence referendum, thus enabling its further devolution, the prevailing feeling of political discontent in Scotland has been stronger than ever.

\section{CONCLUDING REMARKS}

In conclusion, Robertson's creative work represents yet another testimony that the Scottish dream of independence will verily never die. In his short stories discussed here, he severely criticizes the deficient political engagement of his fellow Scotsmen, as well as the current Scottish political representatives and frankly reminds his nation of this remittent social malpractice. From a dissatisfactory utopian vision of independent Scotland's future in Republic of the Mind, Robertson prophetically and ominously portrays his personal premonition of an imminent dystopian disaster in MacTaggart's Shed, as a logical, unfortunate outcome of frequent civil conflicts that his native land may possibly experience soon if the Scottish nation does not finally wake up from its politically indifferent slumber. Thus, his short stories undoubtedly invoke the grand dream that Salmond and his nationalist supporters were talking about, but, at the same time, they pose a potent warning against its potential transformation into a horrible nightmare.

\section{REFERENCES}

Campbell, J. “A Life in Writing: James Robertson.” The Guardian. 14 August 2010. http://www.theguardian. com/books/2010/aug/14/james-robertson-land-still-profile. Accessed 29 March 2016.

Dinwoodie, R. "First Minister: Her Policies Made Scots Believe That Devolution was Essential". The Herald. 9 April 2013. http://www.heraldscotland.com/news/13099442.First_Minister_Her_policies_made_Scots_believe_ that_devolution_was_essential/. Accessed 3 April 2016.

Massie, A. "Republics of the Mind by James Robertson". The Scotsman. 24 November 2012. http://www.scotsman. com/lifestyle/culture/books/book-review-republics-of-the-mind-james-robertson-1-2654157Book review: Republics of the Mind; James Robertson by Alan Massie, Saturday 24 November 2012. Accessed 31 March 2016.

Rich, A. (1993). What is Found There: Notebooks on Poetry and Politics, London: Virago Press.

Robertson, J. (2012). Republics of the Mind. Edinburgh: Black and White Publishing.

Robertson, J. (2005). Voyage of Intent: Sonnets and Essays from the Scottish Parliament. Edinburgh: Scottish Book Trust and Luath Press.

"Scottish referendum: Alex Salmond to quit as first minister". BBC News. BBC. 19 September 2014. http://www.bbc.com/news/uk-scotland-29277527. Accessed 11 April 2016.

Taylor, B. "Scottish Devolution". BBC Scotland. 1997. http://www.bbc.co.uk/news/special/politics97/ devolution/scotland/briefing/scotbrief1.shtml. Accessed 7 April 2016.

Taylor, F. "James Robertson: Republics of the Mind". Contrived Machinery. Review 31. 2012. http://review31. co.uk/article/view/98/contrived-machinery. Accessed 31 March 2016.

Thatcher, M. "Interview with Douglas Keay". Woman's Own. 23 September 1987. http://www.margaretthatcher. org/speeches/displaydocument.asp?docid=106689. Accessed 3 April 2016. 
"The Queen's message following Scotland's referendum". The Royal Household. 19 September 2014 http://www.royal.gov.uk/LatestNewsandDiary/Speechesandarticles/2014/TheQueensmessagefollowingScot landsreferendum.aspx. Accessed 11 April 2016.

Thompson, J. "Book Review: Republics of the Mind: New and Selected Stories by James Robertson". 2012. http://www.arts.gla.ac.uk/ScotLit/ASLS/SWE/TBI/TBIIssue14/ThompsonMind2.html. Accessed 7 April 2016.

Tychy. Short Stories Review: Republics of the Mind. 14 June 2013. https://tychy.wordpress.com/2013/06/14/shortstory-review-republics-of-the-mind/Short Story Review: Republics of the Mind. Accessed 31 March 2016.

Watt, N. (28 September 2014) "David Cameron 'embarrassed and sorry' for saying Queen purred". The Guardian. http://www.theguardian.com/politics/2014/sep/28/david-cameron-sorry-queen-purred. Accessed 11 April 2016.

\section{POTRAGA ZA ŠKOTSKOM NEZAVISNOŠĆU U PRIČAMA DŽEJMSA ROBERTSONA UOČI REFERENDUMA}

Rad se zasniva na detaljnoj analizi Robertsonovih stavova o škotskoj nezavisnosti opisanih u dvema kratkim pričama, Republika uma (1993) i Mektagartova koliba (2012). Budući da između objavljivanja ovih priča postoji uočljiva dugogodišnja pauza, cilj rada predstavlja istraživanje Robertsonovog shavatanja škotske nezavisnosti tokom godina, naročito uzimajući u obzir reference na Referendum o devoluciji (1997) i Referendum o nezavisnosti (2014) u navedenim pričama. Robertson, pobornik ideje o umetniku kao aktivnom društvenom subjektu (Rič 1993), svakako favorizuje koncept škotske nezavisnosti; međutim, u navedenim pričama uočava se izvesna doza sumnje autora u uspešnost buduće realizacije ove ideje, koja se, nakon neuspešnog Referenduma o nezavisnosti (2014), pokazala u potpunosti opravdanom. Teorijski okvir rada počiva na kritičkim uvidima savremenih škotskih književnih teoretičara, Kembela, Tejlora, Tompsona i Mesija, kao i na brojnim novinarskim izveštajima škotskih političkih analitičara.

Ključne reči: nezavisnost, devolucija, Referendum o devoluciji (1997), Referendum o nezavisnosti Škotske (2014) 